\title{
Konsep Pendidikan Akhlak Luqmanul Hakim ( Kajian Tafsir Al-Misbah Dan Al-Maraghi )
}

\author{
Fauziyah Mujayyanah, Benny Prasetiya, Nur Khosiah \\ STAI Muhammadiyah Probolinggo \\ E-mail : fauziyahyana98@gmail.com, prasetiyabenny@gmail.com, Nurkhosiah944@gmail.com
}

Diterima: Desember 2020 ; Dipublikasikan Januari 2021

\begin{abstract}
ABSTRAK
Dampak negative dari era globalisasi yaitu perubahan yang mengarah pada krisisnya akhlak manusia. Dengan demikian, dapat menimbulkan beberapa permasalahan kompleks terkait teknologi dan informasi yang dialami oleh manusia. Beberapa permasalahan kompleks tersebut menjadi tantangan tersendiri bagi seorang pendidik, baik dalam pendidikan formal maupun dalam pendidikan informal. Sebenarnya islam telah memiliki konsep tersendiri dalam mendidikan anak, namun karena perkembangan teknologi yang semakin pesat membuat pendidik kurang memperhatikan dalam mendidik anak khususnya mendidik akhlak seorang anak. Konsep pendidikan akhlak yang dianjurkan oleh syari'at Islam terdapat dalam Alqur'an surah Luqman ayat 12-19. Tujuan penelitian ini adalah: 1) Untuk mengetahui siapakah Luqmanul Hakim dalam Alqur'an; 2) Untuk mengetahui pesan Luqmanul Hakim tentang pendidikan akhlak menurut penafsiran Muhammad Quraish Shihab dalam tafsir Al-Misbah dan Mustafa Al-Maraghi dalam tafsir Al-Maraghi. Penelitian ini menggunakan penelitian kualitatif dengan jenis penelitian library research. Sumber data yang digunakan yaitu sumber data primer yang merupakan sumber data utama yang berkaitan langsung dengan objek riset meliputi: QS Luqman ayat 12-19 beserta terjemahnya, tafsir Al Misbah dan tafsir Al Maraghi kemudian sumber data sekunder yang meliputi: jurnal, hadits, serta buku-buku yang mendukung dan melengkapi data-data primer. Adapun analisis data yang digunakan adalah metode deskriptif. Hasil penelitian menunjukkan bahwa: 1) Luqmanul Hakim merupakan hamba Allah yang mulia dan terpilih sebagai contoh teladan dalam mendidik anak; 2) agar dalam mendidik anak hendaknya didasari dengan kasih sayang yang penuh terhadap anaknya dengan memberikan nasihat-nasihat berupa akidah, tauhid, dan muamalah. Dimana nasihat-nasihat tersebut yang akan mengantarkan anaknya menjadi generasi muda yang mulia, berilmu, berbangsa dan bernegara dengan akhlak yang mulia pula. Kata Kunci: Pendidikan Akhlak, Luqmanul Hakim
\end{abstract}

\begin{abstract}
The negative impact of the globalization era is changes that lead to the crisis of human morality. Thus, it can cause some complex problems related to technology and information experienced by humans. Some of these complex problems become a challenge for an educator, both in formal education and in informal education. Actually Islam has its own concept in educating children, but because of the rapid development of technology, educators pay less attention to educating children, especially educating a child's character. The concept of moral education recommended by Islamic law is contained in the Qur'an Surah Luqman verses 12-19. The aims of this study are: 1) To find out who Luqmanul Hakim is in the Qur'an; 2) To find out Luqmanul Hakim's message about moral education according to the interpretation of Muhammad Quraish Shihab in the interpretation of Al-Misbah and Mustafa Al-Maraghi in the interpretation of Al-Maraghi. This study uses qualitative research with the type of library research. The data sources used are primary data sources which are the main data sources that are directly related to the object of research including: QS Luqman verses 12-19 and their translations, Al Misbah interpretations and Al Maraghi interpretations then secondary data sources which include: journals, hadiths, and books -books that support and complement primary data. The data analysis used is descriptive method. The results showed that: 1) Luqmanul Hakim was a noble servant of Allah and was chosen as a role model in educating children; 2) so that in educating children, it should be based on full love for their children by providing advice in the form of creed, monotheism, and muamalah. Where these advices will lead their children to become noble, knowledgeable, nation and state young people with noble morals as well.
\end{abstract}

Keywords: Moral Education, Luqmanul Hakim 


\section{PENDAHULUAN}

Pendidikan merupakan salah satu aspek yang sangat penting dalam kehidupan baik itu bagi diri sendiri, keluarga dan masyarakat yang berperan untuk meningkatkan kualitas hidup (Khosiah, 2019; Susandi, 2020). Telebih pada pendidikan islam yang memberikan harapoan sebagai agent of change khusunya pada tataran pembentukan moral (Ulil, Hidayah, Benny, 2019). Perkembangan teknologi dirasa sudah cukup memberikan dampak positif bagi kehidupan manusia, dan dampak positifnya hanyalan berperan sebagai fasilitator (mempermudah). Mempermudah segala kehidupan manusia yang selalu disibukkan dengan permasalahan yang kompleks. Teknologi telah memberikan beberapa kenyamanan dan kemudahan yang sangat menggiurkan masyarakat (Syahrul, 2016b).

Namun dengan adanya era globalisasi ini, selain memberikan dampak positif bagi kehidupan manusia tentu memberikan dampak negatif pula terhadap kehidupan manusia telebih dalam karakteristik atau tingkahlaku manusia. Hal ini sudah jelas dirasakan oleh semua pihak dalam masyarakat. Dalam pandangan Prasetiya,( 2018) bahwa Semakin melemahnya nilai-nilai moral dalam sendi kehidupan bermasyarakat baik dalam bidang ekonomi, budaya, sosial, maupun agama memiliki dampak yang besar terhadap gagalnya pelaksanaan pendidikan karakter bagi bangsa Indonesia

Pada umumnya dampak negatifnya adalah menurunkan mental spiritiual manusia dan jiwa manusia yang sedang berkembang dengan segala gaya penampilan. Dampak negatif yang paling berbahaya dari kemajuan yang dialami manusia terhadap kehidupannya adalaah adanya kecenderungan bahwa kebahagiaan manusia hanya bisa diperoleh dengan material. Sehingga manusia lebih memilih untuk mengejar duniawi yang didasari oleh materi dengan menghiraukan segala nilai moral dan spiritiual yang berfungsi sebagai pengendalian akhlak.

Pendidikan yang penuh dengan sarat nilai diharapkan mampu membentuk generasi bangsa yang menjujung tinggi nilai-nilai moralitas dalam bermasyarakat (Prasetiya, Safitri, \& Yulianti, 2019). Manusia akan kehilangan arah dan kendalinya apabila nilai-nilai moral dan spiritual ia tinggalkan, sehingga akan sangat mudah terjatuh ke dalam tindakan penyelewengan dan kerusakan akhak. Seperti halnya merampas hak dari oranglain, tindakan kriminal, dan seksual. Sebagai contoh ada beberapa kasus yang tak bermoral yang terjadi di Negara kita saat ini yaitu sebuah tayangan dalam televisi yang memuat berita bahwa seorang anak melaporkan ibu kandungnya ke kantor polisi hanya karena masalah kecil, kemudian disusul dengan berita dari dunia entertainment dimana salah satu aktor pemain FTV yang terjerat kasus narkoba.

Kasus-kasus tersebut diatas merupakan kejadian fakta bentuk kerusakan moral dan akhlak yang tersebar luas di dalam lingkup masyarakat. Selain itu, dampak negatif globalisasi ini adalah adanya persaingan yang tidak sehat antar kelompok.

Oleh sebab itu sangat perlu adanya penanaman akhlak yang baik bagi setiap individu agar bisa menjadi manusia harapan Tuhan, yakni sebagai khalifah di dunia. Kita yang dilahirkan sebagai anak akan mengambil contoh dari orangtua dan keluarga karena keduanya ini merupakan sekolah pertama bagi seorng anak. Anak selalu terlahir dalam keadaan bersih seperti kertas putih, maka dengan didikan orangtua dan keluarga yang akan memberikan warna pada kertas putih itu.

Dalam pandangan hukum Islam, anak merupakan karunia Allah yang indah yang diberikan kepada orangtua sebagai bentuk amanat dari-Nya. Sehingga orantua mempunyai kewajiban untuk memelihara dan mendidik amanta tersebut dengan baik.

Alqur'an telah menggambarkan bahwa anak merupakan sumber kehidupan bagi manusia, sehingga kehadiran anak membuat keluarga itu lebih lengkap, harmonis, dan bahagia. Pun sebaliknya, ketidak hadiran anak membuat keluarga itu mati tanpa ada kebahagiaan.

Kehadiran anak yang diungkapkan dalam Alqur'an ini dapat terwujud apabila orang tuanya telah mempersiapkannya sejak dini. (Anisah, 2011).

Mewujudkan anak yang memiliki kualitas baik merupakan tanggungjawab orangtuanya, oleh karena itu orang tua wajib memelihara, merawat, membesarkan, memberikan pendidikan dengan penuh tanggungjawab dan kasih sayang kepada anaknya serta memberikan pendidikan agama yang baik dan benar sebagai bekal untuk lebih dekat kepada Allah dan siap menghadapkan diri kepada Allah.

Sebagaimana perintah Allah kepada orangtua untuk menjaga anak-anaknya agar terhindar dari kejelekan, kerugian, dan dari api neraka. Allah telah mengingatkan kita agar tidak mewariskan 
generasi-generasi yang lemah. Baik generasi yang lemah aqidahnya, moral atau akhlaknya, dan juga generasi yang lemah akan ekonominya. Karena, apabila kita mewariskan generasi seperti yang disebutkan di atas maka secara tidak langsung kita memberikan peluang untuk pengaruh dari globalisasi ini masuk dan meresap dalam dirinya.

Oleh karena itu, pendidikan dalam pembentukan karakter anak memang harus diperhatikan dengan sangat baik. Sehingga pendidikan ini bukan hanya ditentukan oleh keturunan dan lingkungan saja, tetapi juga dipengaruhi oleh kemampuan orangtua dalam mendidik, mengarahkan, dan mempengaruhi serta membentuk akhlak anak yang baik.

Kualitas pemahaman agama dan integrasi nilai-nilai agama dalam kehidipan bermasyarakat nampaknya sangat sulit dipisahkan dari proses penyelenggaraan lembaga pendidikan agama baik formal maupun informal. Dengan demikian maka perlu dilakukan sebuah pengkajian mendalam terhadap peran pendidikan agama di lingkungan keluarga, masyarakat maupun institusi pendidikan formal (Prasetiya, Rofi, \& Setiawan, 2018). Pendidikan merupakan kegiatan yang terdiri dari dua orang atau lebih antara pendidik dengan peserta didik untuk mencapai tujuan pendidikan yang telah ditetapkan. Kegiatan ini dapat berlangsung dalam sekolah, keluarga, ataupun lingkup masyarakat.

Pendidikan memiliki fungsi sebagai alat untuk membantu peserta didik agar menjadi generasi yang lebih baik, baik dari segi potensi, skill, dan kepribadiannya untuk dirinya maupun lingkungan masyarakat (Syaefulloh, 2016; (Naimah \& Hidayah, 2017). endidikan karakter akan membangun dengan baik, jika dimulai dari menumbuhkan rasa keagamaan siswa, oleh karena itu, pelajaran PAI menjadi salah satu pelajaran pendukung pendidikan karakter (Rofi, Prasetiya, \& Setiawan, 2019).

Dalam Islam, tujuan pendidikan adalah menciptakan manusia yang baik lahir dan batinnya. Namun, tujuan ini tidak akan tercapai dengan maksimal apabila konsep pendidikannya tidak berlandaskan pada nilai-nilai Alqur'an. Alqur'an dan Hadist merupakan sumber ajaran utama agama Islam yang telah menetapkan segala aturan untuk sebuah hubungan dalam keluarga yakni dalam pembinaan dan pembentukan akhlak mulia. Alqur'an diturunkan secara berangsur-angsur dengan ayat-ayatnya yang saling berkesinambungan dengan adat dan istiadat masyarakat. Dengan begitu, segala nilai yang terkandung di dalamnya dapat diinterpretasikan dalam segala kondisi dan bersifat dinamis. Sehingga Alqur'an sangat cocok menjadi pedoman dan petunjuk dalam setiap hal yang dihadapi manusia uantuk menentukan mana yang haq dan yang batil.

Alqur'an yang dijadikan sebagai sumber pokok ajaran islam di dalamnya terdapat kisah dari seorang hamba Allah yang menjalankan pendidikan sesuai dengan konsep Alqur'an terhadap pendidikan anaknya. Sehingga peranan pendidik dan orangtua sangat diharapkan untuk dapat memberikan contoh teladan sesuai ajaran Alqur'an terhadap peserta didik dan anak-anaknya. Oleh sebab itu sangat penting menjadikan Alqur'an sebagai acuan dalam penggalian informasi untuk mendapatkan berbagai solusi dalam masalah kehidupan (Emilya, 2017).

Untuk mempelajari pendidikan akhlak dalam pendidikan Islam, rujukan dasar yang sangat cocok adalah Alqur'an. Sebagai perwakilan Alqur'an yakni Tafsir, karena Tafsir merupakan kunci utama dalam penggalian ilmu yang terkandung dalam Alqur'an dan ilmu tersebut sangat bermanfaat bagi kehidupan manusia untuk lebih baik. Tanpa adanya Tafsir, ilmu tersebut tidak akan berguna meski dalam pembacaan Alqur'annya telah berulang kali (Budi, 2018). Tafsir Al-Misbah dan Tafsir Al-Maraghi merupakan dua Tafsir yang penafsirannya memiliki perbedaan.

Tafsir Al-Misbah yang disusun oleh Muhammad Quraish Shihab pada 18 Juni 1999, di Kairo. Tafsir ini merupakan tafsir dengan corak penulisan al-Adabi al-Ijtima'i atau sosialisme, sebab penjelasannya mengarah pada permasalahan yang terjadi dalam masyarakat atau rasio kultur masyarakat. Tafsir ini juga menggunakan dua metodologi penafsiran, yakni metode tahlili dan metode maudhu'i. Tafsir Al-Misbah mampu menterjemahkan dan menyampaikan isi pesan Alqur'an dengan latar belakang masa kini dan modern. Di sisi lain penggunaan dalam tafsir tersebut adalah bahasa Indonesia sehingga pembacanya dapat dengan mudah memahami isi kandungan Alqur'an tersebut (Ayu, 2015).

Sedangkan, Tafsir Al-Maraghi merupakan tafsir yang disusun oleh Ahmad Mustafa Ibn Mustafa Ibn Muhammad Ibn ‘Abd al Mun'im al-Maraghi. Ahmad Mustafa lahir di Maraghi, Propinsi Suhaj, kurang lebih $700 \mathrm{~km}$ ke arah selatan Kairo. Tafsir ini merupakan salah satu tafsir yang terbaik dan terkenal di era ini, karena memaparkan dua atau lebih ayat Alqur'an secara bahasa dengan tujuan yang terpadu (Budi, 2018). 
Dengan diterjemahkan dalam Tafsir Al-Misbah dan Tafsir Al-Maraghi sudah pasti di dalamnya memuat pendidikan akhla yang harus dicontoh oleh umat Islam. Apabila di dalam keluarga menerapkan pendidikan akhlak dengan landasan Alqur'an dan mengambil teladan dari Nabi atau utusan Allah, maka keberhasilan yang dicapai sudah tidak diragukan lagi karena semua itu telah terbukti bahkan dicantumkan di dalam Alqur'an.

Terdapat banyak kisah di dalam Alqur'an yang dijabarkan hanya peristiwanya saja, sedangkan waktu, tempat, alur cerita, dan juga pelakunya tidak disebutkan. Begitu juga dengan kisah Luqman dalam surah ini. Alqur'an hanya menjabarkan bahwa ia merupakan seorang hamba yang mendapat hikmah dari Allah SWT.

Kendatipun bukan seorang nabi, Luqman mendapati kedudukan yang tinggi. Karena, kedudukan derajat manusia yang tinggi ialah manusia yang kamil fi nafsih wa mukmil li ghayrih, yakni orang yang dirinya telah mencapai kesempurnaan dan berupaya untuk menyempurnakan oranglain. Kelebihan daripada Luqman tercantum dalam ayat 12 surah Luqman, bahwa ia termasuk seorang hamba yang mendapat karunia Allah berupa limpahan hikmah dari-Nya. Adapun usaha yang ia lakukan untuk menyempurnakan oranglain terlihat dalam nasihatnya kepada anaknya (Emilya, 2017). Adapun konsep pendidikan akhlak yang telah Allah ajarkan kepada kita tercantum di dalam Alqur'an Surah Luqman ayat 12-19.

Dengan menganalisis realita kehidupan yang di dalamnya terdapat permasalahan kompleks seperti yang telah disebutkan, maka dengan ini penulis mencoba mengkaji lebih dalam lagi tentang bagaimana konsep pendidikan akhlak yang sesuai dengan ajaran Alqur'an dalam sebuah skripsi yang berjudul "KONSEP PENDIDIKAN AKHLAK LUQMANUL HAKIM (Kajian Tafsir Al-Misbah dan Al-Maraghi)"

\section{METODE PENELITIAN}

Penelitian yang digunakan dalam penulisan ini adalah penelitian kualitatif dengan menggunakan jenis penelitian kepustakaan (Library Research) yakni dengan mengulas buku atau data tertulis yang berkesinambungan dengan penulisan skripsi ini. Dalam hal ini, peneliti menganalisis beberapa data terkait yang terpapar dalam Alqur'an, Kitab Tafsir, buku-buku dan artikel hasil dari observasi para peneliti yang penulis jadikan referensi utama.

Untuk pendekatan yang digunakan, penulis menggunakan pendekatan historis dan filosofis. Dimana pendekatan historis ini ditujukan untuk mengulas dan meenyingkap pendidikan akhlak yang diterapkan oleh Luqman Hakim sebagaimana termaktub dalam surah Luqman ayat 12-19 berupa asbabun nuzul dan kisahnya. Sedangkan, pendekatan filosofis ditujukan untuk membahas dan menjelaskan secara detail mengenai konsep pendidikan akhlak Luqman Hakim yang terpapar dalam pemikiran Muhammad Quraish Shihab dalam Tafsir Al-Misbah dan juga pemikiran Mustafa AlMaraghi dalam Tafsir Al-Maraghi.

Untuk melengkapi data dalam penulisan skripsi ini, maka dilakukan dengan upaya melalui beberapa tahapan yakni : orientasi, eksplorasi dan terfokus (Arif \& Agus, 2005).

Tahap orientasi, peneliti menghimpun data-data umum yang akan diambil perihal yang penting dan menarik untuk diteliti. Pada tahap eksplorasi, mengumpulkan data yang dibutuhkan dengan batasan hal-hal yang bermakna dan terarah. Sedangkan pada tahap terfokus, berusaha mengamati pembahasan dari data yang diteliti.

Sebelum menjelaskan jenis penelitian penulisan ini, penulis menghimpun beberapa data yang memiliki keterkaitan dengan permasalahan dalam penelitian ini. Adapun data tersebut berupa sumber primer dan sumber sekunder yang diantaranya sebagai berikut:

1. Sumber primer merupakan sumber data yang dijelaskan oleh orang pertama, (Muhajir, 1996:5) yaitu sumber utama yang dijadikan dasar dalam penulisan ini (Nur, 2018). Sumber primer dalam penelitian ini adalah Alqur'an dan terjemahnya, tafsir Al Misbah karya Muhammad Quraish Shihab dan tafsir Al Maraghi karya Mustafa Al-Maraghi.

2. Sumber sekunder ialah sumber data modifikasi dari sumber pertama, yaitu data yang dijadikan sebagai bahan kajian pendukung (Barnadib, 1982:55) (Nur, 2018). Data sekunder meliputi artikel, jurnal, skripsi,dan thesis yang berkaitan dengan judul penelitian. 
Adapun teknik analisis yang digunakan adalah metode deskriptif. Metode deskriptif ialah menuangkan data dengan cara memperjelas sesuai dengan data dari hasil penelitian. Karena tujuan teknik analisis ialah memudahkan pembaca dalam memahami isi dan mengaplikasikannya (Brata, 1997:19). Kemudian menganalisis suatu pernyataan secara konseptual sehingga memperoleh kejelasan arti dari kandungan pernyataan tersebut.

Metode deskriptif dalam penelitian ini diwujudkan melalui dua cara, yaitu: deduktif dan induktif. Deduktif merupakan pendekatan yang dilakukan dari yang umum ke yang khusus (Swarjana, 2012:5). Maka penulis mengumpulkan data mengenai surat Luqman dengan metode tahlili, kemudian berdasarkan data yang telah diperoleh, penulis menganalisis konsep pendidikan akhlak Luqmanul Hakim, dan menggolongkannya secara khusus sesuai tafsir Al Misbah dan Al Maraghi.

Penulis juga menggunakan pendekatan induktif, pendekatan ini dilakukan dari yang khusus ke yang umum (Swarjana, 2012: 5). Penulis memulainya dengan penemuan fenomena, kasus, kejadian, atau permasalahan yang ada di masyarakat, kemudian penulis melakukan analisis surah Luqman yang akhirnya akan menghasilkan kesimpulan terkait dengan konsep pendidikan akhlak Luqmanul Hakim (Nur, 2018).

\section{HASIL DAN PEMBAHASAN}

\section{Tafsir Surah Luqman Ayat 12 - 19 dalam Tafsir Al Misbah dan Tafsir Al Maraghi Penafsiran Ayat 12 - 19 dalam Tafsir Al Misbah}

Pada ayat 12, menjelaskan bahwa Allah telah memberikan ilmu, agama, akal pikiran, kebijakan dan kebenaran dalam berucap kepada Luqman Hakim, sehingga mengantarkannya pada kebahagiaan yang kekal seraya menjelaskan beberapa butir hikmah yang disampaikannya pada anaknya (Halimah, 2017).

Ayat ini juga menjelaskan bahwa Allah memerintahkan untuk selalu bersyukur kepada-Nya untuk kepentingan dirinya sendiri, dan apabila ada yang tidak bersyukur maka yang merugi juga dirinya sendiri. Sesungguhnya hal ini tidak berpengaruh terhadap kekuasaan Allah, karena sesungguhnya Allah Maha Kaya (Ayu, 2015).

Kata dan pada awal ayat di atas berhubungan dengan surah Luqman ayat 6, yang mana dalam ayat itu menghubungkan kisah an-Nadhr Ibn al-Harits dalam ayat 6 surah Luqman dengan kisah Luqman pada ayat 12 tentang penganugerahan hikmah kepada dua orang tersebut. (Aida, 2019).

Kata hikmah telah disinggung maknanya ketika menafsirkan ayat 12. Dalam hal lain, Muhammad Quraish Shihab menambahkan bahwa beberapa ulama memiliki bermacam-macam makna mengenai kata hikmah. Antara lain bahwa hikmah berarti "Mengetahui hal utama dari sesuatu yang baik berupa pengetahuan dan perbuatan. Hikmah adalah ilmu yang berdasarkan oleh amal, dan amal yang benar berdasarkan oleh ilmu".

M. Quraish Shihab dalam Tafsir Al Misbah menjelaskan bahwa Luqman Hakim telah dikaruniai Allah sebuah hikmah dengan menyampaikan beberapa butir hikmah yang telah disampaikan kepada anaknya . Kata Hikmah berasal dari hakamah yang bermakna kendali. Kendali memiliki arti mengahalangi sesuatu yang mengarah pada keburukan atau hal yang tidak diinginkan. Perwujudan hikmah dapat berupa seperti memilih perbuatan yang baik dan telah sesuai dengan ketentuan. Memilih yang baik dan sesuai dengan ketentuan dari hal yang buruk juga disebut hikmah dan pelakunya disebut hakim. Hikmah juga diartikan suatu hal yang digunakan untuk mencegah keburukan yang besar maka akan mendatangkan kebaikan yang besar pula.

Kata syukur berasal dari kata syakara yang bermakna pujian atas kebaikan suatu hal. Rasa syukur kepada Allah diawali dengan menyadari nikmat dan berkah-Nya pada ruang hatinya yang paling dalam dengan dasar kagum dan tunduk pada-Nya yang dapat menciptakan rasa cinta dan memuji-Nya dengan kata-kata indah sebagai wujud rasa syukur-Nya. Sayyid Qutb menulis bahwa "Hikmah, makna dan dampaknya adalah syukur kepada Allah." Hikmah berarti syukur, karena dengan memiliki rasa syukur kepada Allah, maka orang tersebut telah mengenal Allah dan karuniaNya (Eka, 2017). 
Dalam surah ini Luqman merupakan tokoh yang masih diperdebatkan asal usulnya, masyarakat Arab mengenal dua orang yang bernama Luqman. Yang pertama, Luqman ibn 'Ad, dia diunggulkan sebab berwibawa, kepemimpinannya, ilmu, kefasihan, dan kepandaiannya. Dan yang kedua, ialah Luqman Hakim yang terkenal dengan kebijaksanaannya dalam berucap, dan sepertinya Luqman inilah yang dimaksud oleh surah ini. Sahabat Nabi, ibn Umar ra., menyatakan bahwa Nabi pernah bersabda bahwasanya Luqman bukanlah seorang nabi, melainkan seorang hamba Allah yang dianugerahkan hikmah karena dia mencintai Allah dengan bukti banyak melakukan kebaikan, banyak merenung dan keyakinannya lurus (Ayu, 2015).

Pada ayat 13, M. Quraish Shihab menafsirkan : kata ya 'izhuhu diambil dari kata wa'zh yaitu sebuah nasihat mengenai kebaikan yang dilakukan dengan memberi sentuhan hati. Ada pula yang menafsirkan sebuah ucapan yang memiliki makna peringatan. Penyebutan kata ini sesudah kata dia berkata untuk memberikan perumpamaan bahwa perkataan itu beliau sampaikan dengan nada yang tidak kasar, lemah lembut, dan dengan penuh kasih sayang, sebagaimana dia memanggil anaknya dengan mesra. Selanjutnya kata bunnayya adalah salah satu dukungan yang menjabarkan kemungilan. Kemungilan tersebut menunjukkan kasih sayang. Sehingga, dapat disimpulkan bahwa dalam mendidik anak haruslah didasari dengan kasih sayang (Ayu, 2015).

Pada ayat 14, M. Quraish Shihab menafsirkan: Bahwa ayat ini dan selanjutnya bukan menjelaskan tentang pendidikan Luqman terhadap anaknya. Ayat ini dicantumkan untuk menjelaskan perintah hormat dan berbakti kepada kedua orang tua, yang mana hal ini menempati kedudukan kedua setelah perintah patuh dan tunduk kepada Allah SWT. Walaupun ayat ini bukan merupakan nasihat Luqman kepada anaknya, bukan beearti Luqman tidak memberikan nasihat yang serupa kepada anaknya. Adapun nasihat tersebut disampaikan secara langsung atau tidak, yang jelas ayat ini telah memberikan pesan yang sangat mengenai kebaktian kepada kedua orang tuanya.

Walaupun dalam ayat ini tidak menyebut bapak, bukan berarti jasa bapak tidak untuk diharg ai. Hal ini menunjukkan untuk memberikan perhatian lebih kepada seorang ibu karena mengalami kesusahan dalam mengandung hingga melahirkan, sehingga bebannya melebihi seorang bapak. Oleh karena itu, berbaktinya anak kepada orang tua tidak harus mendahulukan seorang ibu atau bapak tetapi pengabdian anak harus didasari oleh kebijaksanaan dengan melihat siapa yang lebih diutamakan (Ayu, 2015).

Pada ayat 15, ayat ini menjelaskan pengecualian berbakti dan menaati perintah orang tua. Maka M. Quraish Shihab menafsirkan : Apabila kedua orang tuamu atau salah satunya memaksamu untuk mempersekutukan Allah, maka janganlah kau mematuhinya. Namun, janganlah pula kau memutuskan hubungan dengan keduanya. Tetaplah taat dan berbakti kepadanya selama tidak bertentangan dengan ajaran agamamu dan pergaulilah keduanya di dunia ini dengan cara membina hubungan yang baik (Ayu, 2015).

Pada ayat 16, ayat ini merupakan lanjutan nasihat Luqman kepada anaknya yang menjelaskan kedalaman ilmu Allah SWT. Nasihat itu berisi : bahwasanyaAllah Maha Mengetahui segala sesuatu yang tersembunyi baik dalam hal kebaikan ataupun keburukan. Walaupun perbuatan itu seberat biji sawi dan berada di tempat yang paling tersembunyi, nicaya Allah dapat melihatnya dan akan memberikan ganjaran balasan atas perbuatannya kelak di Akhirat. Dan sesungguhnya Allah itu Maha Halus dalam menjangkau sesuatu

Kata lathif dalam ayat ini memiliki makna kecil, halus, dan lembut. Dari makna tersebut maka tercipta kata kejelian dan ketelitian. Allah bersifat Lathif, karena Dia berkehendak atas makhlukNya, baik untuk kesulitan ataupun kemudahan. Maka, kesimpulan dari ayat ini adalah menjelaskan kekuasaan Allah atas makhluk-Nya dengan melakukan hitungan amal kebaikan di akhirat nanti (Siti, 2016).

Pada ayat 17, dalam ayat ini Luqman melanjutkan nasihatnnya yakni mengenai hubungan tauhid dengan menghadirkan Allah di dalam hati seorang anak. Nasihat yang beliau sampaikan ialah: memberikan perintah kepada anaknya untuk melaksanakan shalat dengan sempurna sebagai benteng diri dari perbuatan keji. Selain itu ajaklah orang lain untuk melakukan hal yang serupa. Sesungguhnya, dalam melaksanakan perintah Allah banyak halangan dan rintangan yang menghalangi sehingga bersabarlah dalam mengerjakan kewajiban itu. Karena sesungguhnya perbuatan yang memiliki kedudukan tertinggi dalam kebaikan yakni shalat, amr ma'ruf dan nahi munkar, dan kesabaran dalam mengerjakan kebaikan.(Ilham, 2017). 
Pada ayat 18 dan 19, kedua ayat ini menjelaskan mengenai nasihat Luqman untuk memelihara sopan santun dan akhlak yang baik. Adapun nasihat yang beliau sampaikan adalah : Pertama, janganlah memalingkan wajah dari siapa pun karena hal ini merupakan sebuah penghinaan dan kesombongan, namun tampakkanlah wajah yang ceria dengan kerendahan hati. Kedua,apabila berjalan janganlah berjalan dengan angkuh, namun berjalanlah dengan penuh kewibawaan dan langkah yang elok. Karena sesungguhnya Allah tidak menyukai orang yang sombong dan membanggakan dirinya. Ketiga, tunjukkanlah kesederhanaan dalam langkah berjalanmu dengan merunduk, janganlah berlari terburu-buru dan janganlah membuang waktu. Keempat, rendahkanlah suaramu dalam berbicara sehingga tidak terdengar kasar bagaikan teriakan keledai. Sesungguhnya seburuk-buruk suara ialah suara keledai (Suci, 2019).

\section{Penafsiran Ayat 12 - 19 dalam Tafsir Al Maraghi}

Pada ayat 12, Hikmah yang dianugerahkan Allah kepada Luqman menurut Al Maraghi ialah kebijaksanaan dan kecerdikan. Diantara hikmahnya adalah ia selalu mensyukuri atas segala nikmat dan karunia-Nya dengan memuji-Nya, karena sesungguhnya pujian dan rasa syukur hanya patut diberikan kepada-Nya. Kemudian Maraghi mengatakan siapa saja yang besyukur maka manfaat dari syukur itu akan kembali pada dirinya sendiri. Hal ini juga disampaikan dalam ayat 12 surah Luqman. Sesungguhnya Allah hendak memberikan limpahan pahala atas balasan rasa syukurnya kepada Allah yang nantinya akan menjadi penyelamat baginya dari azab Allah. Demikian Al-Maraghi menjelaskannya.

Kemudian Al-Maragī menjelaskan bahwa bagi mereka yang kufur maka bersiaplah untuk menerima kosekuensi atas apa yang telah ia perbuat, yaitu suatu akibat buruk berupa siksa atasnya karena kekufuran akan segala nikmat yang Allah beri. Dan Allah Maha Kaya atas rasa syukurnya, karena bentuk rasa syukur dari manusia tidak berpengaruh apapun bagi kekuasaan-Nya, begitu pula dengan kekafiran manusia juga tidak mengurangi apapun bagi kekuasaan-Nya. Sesungguhnya Dia Maha Terpuji dalam setiap kondisi, baik hambanya kafir atau besyukur.

Pada ayat selanjutnya, Al Maraghi menjelaskan makna mengingatkan orang lain dengan cara yang halus, agar hatinya dapat luluh karena hal itu. Sangat terbukti, bahwa betapa sayang dan cintanya Luqman kepada anaknya sehingga ia memerintah anaknya untuk hanya menyembah Allah dan tidak melakukan kemusyrikan (menyekutukan Allah dengan selain-Nya). Hal ini terkandung di dalam ayat 13 Q.S. Luqman.

Luqman memberikan penjelasan kepada anaknya bahwasanya perbuatan syirik atau musyrik merupakan kedzoliman kepada Allah yang sangat besar. Mengapa demikian? karena syirik adalah meletakkan sesuatu yang tidak pada tempatnya. Kemudian Maragī menambahkan penjelasan tentang syirik dengan mengatakan bahwa Imam Bukhori telah meriwayatkan sebuah hadis yang bersumber dari Ibnu Mas"ud telah menceritakan, bahwa ketika ayat dalam QS. Al-An'am: 82 di turunkan, maka hal tersebut dirasa amat berat oleh para sahabatnya, kemudian mereka pun bertanya kepada Rasulullah SAW tentang siapakah ia yang mencampuradukkan antara iman dan kedzoliman (dosa)? Maka Rasul pun menjawab pengertian kedzoliman bukanlah demikian, pernahkah kalian mendengar perkataan Luqman yang terkandung dalam Q.S.Luqman ayat 13 ?

Setelah Luqman mengatakan wasiatnya kepada anaknya untuk agar selalu bersyukur atas nikmat yang telah Allah limpahkan, dan tiada seorang pun yang bersekutu dengan-Nya dalam menciptakan sesuatu. Kemudian Luqman menegaskan bahwa syirik adalah perbuatan yang buruk dan keji. Hal ini terkandung dalam Q.S.Luqman ayat 13.

Kemudian Allah mengiringi hal tersebut dengan nasihat Luqman agar patuh dan berbakti kepada kedua orangtuanya, karena dengan adanya orangtuanya ia hadir dalam dunia. Hal ini sebagaimana termaktub dalam ayat 14 QS Luqman.

Allah memerintahkan agar kita senantiasa patuh, berbakti dan memenuhi segala hak-hak kedua orangtuanya. Alqur'an kerap menggandengkan perintah taat kepada Allah dengan perintah berbakti kepada orantuanya.

Pada lanjutan surat Luqman ayat 14, Allah menyebutkan dengan khusus jasa seorang ibu terhadap anaknya, karena seorang ibutelah mengalami banyak kesulitan yang sangat berat mulaidari mengandung hingga melahirkan anaknya. 
Menurut Al Maraghi perintah berbakti pada kedua orang tua dengan menyebutkan ibu saja karena pihak ibulah yang telah mengalami kesulitan yang lebih besar. Kesulitan besar yang dialami ibu ketika mengandung anaknya hingga melahirkan dan merawatnya siang malam.

Al Maraghi menambahkan keterangannya dengan riwayat Rasulullah Saw yang suatu ketika didatangi oleh sahabat dan bertanya tentang siapakah orang yang sangat berhak untuk dipatuhi dan berbakti kepadanya. Maka Rasulullah Saw menjawab pertama ibumu, kedua ibumu, ketiga ibumu, kemudian barulah ayahmu.

Setelah Allah menegaskan untuk senantiasa berlaku baik pada kedua orang tua dengan pemenuhan segala haknya. Lalu Allah mengecualikan dari hal-hal tersebut apabila keduanya mengajak untuk melakukan hal-hal yang membuat Allah murka.

Al-Maraghi pun menambahkan penjelasannya dengan menceritakan sebuah riwayat bekenaan dengan Sa'ad ibnu Abi Waqas yang bercerita ketika ia masuk islam, maka ibunya tidak mau makan dan minum. Lalu, ia membujuk ibunya sampai tiga kali agar ia mau makan dan minum. Namun, ibunya tetap menolak dan tetap pada prinsipnya. Maka Sa'ad ibnu Abi Waqas bekata, "Demi Allah seandainya engkau mempunyai seratus nyawa maka semua itu akan keluar dan aku tidak akan meninggalkan agamaku ini." Ketika ibunya melihat bahwasannya ia benar-benar tidak mau mengikuti kemauannya, akhirnya ibunya mau makan.

Pada lanjutan penggalan ayat tersebut, terdapat perintah untuk mempergauli keduanya dengan dengan baik, yakni memberikan sandang pangan kepada keduanya, tidak berlaku kasar kepadanya, menjenguk dan merawatnya jika sakit, serta menguburkanya jika meninggal dunia.

Firman-Nya fid dunya menggambarkan bahwa mempergaulinya merupakan suatu hal yang mudah dilakukan. Karena sesungguhnya hal itu tidak seterusnya terjadi, sehingga tidak menjadi beban berat.

Dan karena melihat hal itu terkadang seseorang rela mengorbankan agamanya sebab danya hubungan timbal balik. Sehingga Allah menjelaskan lagi pada lanjutan penggalan ayat 15 ini dengan makna ikutilah jalan orang-orang yang telah bertaubat atas kemusyrikannya dan kembali kepada agama Islam serta ikutilah jejak Rasulmu. Kemudian Al Maraghi menyimpulkan lanjutan dari penggalan ayat tersebut bahwa ikutilah jalan Allah dengan mengeesakan-Nya serta taatlah kepada Allah.

Lalu setelah kalian mati, kalian akan kembali kepada-Ku. Dan kemudian aku kabarkan kepada kalian semua perbuatan baik dan buruk kalian selama masih di dunia. Kemudian, Aku memberikan ganjaran kepada kalian sesuai dengan apa yang kalian perbuat semasa hidup di dunia.

Selanjutnya, Allah melanjutkan kembali lanjutan amanat Luqman kepada anaknya dalam ayat 16 Q.S. Luqman, yang pada awalnya Luqman melarang anaknya untuk berbuat syirik.

Al Maraghi menjelaskan bahwa segala amal baik dan buruk walaupun hanya sebesar biji sawi, lalu tersembunyi sekalipun bahkan tidak terlihat seperti di dalam bumi, maka sesungguhnya akan terlihat oleh Allah SWT. kelak di hari kiamat. Sesungguhnya Allah Maha Halus akan semua pengetahuan-Nya sekalipun hal-hal yang tidak terlihat, lagi Maha Waspada, Dia mengetahui semua perbuatan yang terlihat ataupun tidak.

Pada Ayat 17, memiliki arti Hai anakku laksanakanlah sholat dengan sempurna sesuai dengan cara yang diajarkan dalam agama Islam. Karena dalam sholat mengandung keridhaan-Nya, sebab siapa yang mengerjakannya maka ia tunduk dan mengahadp kepada Tuhannya. Bukan hanya itu, sholat juga memiliki manfaat lain yaitu menahan dari kekejian dan kemungkaran. Maka barangsiapa yang menunaikannya dengan sempurna, niscaya jiwanya bersih dan berserah diri kepada Allah dalam keadaan suka maupun duka.

Setelah Luqman menasihati anaknya agar menyempurnakan dirinya untuk memenuhi perintah Tuhannya, kemudian ia memerintahkan anaknya agar memenuhi haknya terhadap orang lain.

Sehingga, amanah ini diawali dengan perintah melaksanakan sholat yang kemudian diakhiri dengan nasihat untuk sabar, karena sesungguhnya dua perkara itu merupakan cara untuk mendapatkan ridha Allah SWT.

Kemudian Al Maraghi mengatakan bahwa Luqman selain telah mewasiatkan kepada anakanaknya beberapa nasihat di atas. Ia juga mewasiatkan hal-hal lainnya, yang tercantum dalam kelanjutan ayat berikutnya pada surat Luqman 18 hingga 19, diantaranya yaitu: 
Pertama, agar sebaiknya kamu tidak memalingkan wajah saat berbicara dengan seseorang yang sedang kamu ajak berbicara karena dapat disebut sombong. Sehingga hadapilah dengan wajah yang gembira.

Kedua, dan larangan berjalan dengan angkuh dan sombong terhadap diri sendiri. Karena hal itu termasuk cara jalannya orang- orang yang sombong dan angkara murka, yaitu orang-orang yang senang melakukan kekejian di bumi dan melakukan kedzaliman kepada orang lain. Sementara berjalan dengan sederhana berarti mencerminkan jalannya orang yang rendaah diri. Kemudian Luqman menjelaskan illat dari larangannya itu. Sesungguhnya Allah tidak suka terhadap orang yang angkuh atau menyombongkan diri dan bersikap sombong kepada orang lain.

Ketiga, Dan berjalanlah dengan langkah yang baik dan sederhana tanpa tergesa-gesa.

Keempat, Janganlah mengeraskan suaramu ketika berbicara dan jika tidak dibutuhkan. Karena sesungguhnya perilaku yang seperti ini lebih berwibawa dan lebih nyaman diterima oleh orang lain.

Dengan illat yang dijelaskan oleh Luqman pada terusan ayat ini bahwa seburuk-buruknya suara yang dikeraskan melebihi tanpa adanya sebab adalah seburuk suara keledai . Dengan demikian ungkapan ini jelas mengandung hinaan bagi mereka yang mengeraskan suaranya melebihi apa yang dibutuhkan dan untuk membenci perbuatan itu.

Sementara ugkapan bagi mereka yang mengeraskan suara yang diibaratkan dengan suara keledai, mengandung pemberitahuan yang penting untuk menanamkan rasa menolak dari perbuatan tersebut, karena Allah sungguh sangat membencinya. Demikianlah Allah mengajarkan umatnya untuk tidak mengeraskan suaranya di hadapan orang- orang ataupun dengan maksud meninggalkan perbuatan ini secara menyeluruh (Syahrul, 2016a).

\section{KESIMPULAN}

Dari uraian di atas, dapat diambil kesimpulan bahwa Luqman Hakim yang namanya diistimewakan sebagai nama salah satu surah dalam Alqur'an adalah seorang hamba Allah yang memiliki sikap mulia dan terpilih sebagai teladan yang baik dalam memberikan pendidikan terhadap anak-anaknya. Dia bukanlah seorang Nabi, namun dia hanya seorang hamba yang saleh dan dianugerahi hikmah sehingga lebih banyak disebut dengan Luqman al-Hakim. Adapun terkait asal-usulnya hingga kini belum diketahui secara pasti darimana asal Luqman Hakim yang sesungguhnya, hal ini dikarenakan kurangnya riwayat-riwayat yang membicarakan tentang Luqman Hakim. Ada yang menyebutkan bahwa Luqman Hakim berasal dari Mesir Selatan, adapula yang mengatakan ia berasal dari Ibrani. Sedangkan, yang menyebutkan bahwa Luqman berasal dari Ethiopia adalah pendapat menurut Muhammad Quraish Shihab dalam tafsirnya yakni Tafsir $A l$ Misbah. Selain itu, terkait dengan profesi Luqman juga masih dipertentangkan. Ada yang menyebutkan ia merupakan seorang penjahit, pengumpul kayu, atau tukang kayu. Islam telah memberikan bimbingan dan petunjuk serta memberikan contoh konsep pendidikan akhlak bagi anak, untuk dapat menciptakan generasi muda yang beragama, berbangsa dan bernegara dengan akhlak yang mulia. Inilah yang dijelaskan Allah dalam Alqur'an surah Luqman ayat 12-19.

Penafsiran Muhammad Quraish Shihab dan Mustafa Al Maraaghi terhadap Q.S Luqman ayat 12-19 mengenai pendidikan akhlak Luqman Hakim yaitu agar dalam mendidik anak alangkah baiknya didasari oleh rasa penuh kasih sayang terhadap anaknya dengan memberikan nasihat-nasihat berupa akidah, Tauhid, dan muamalah. Dimana nasihat-nasihat tersebut yang akan mengantarkan anaknya menjadi generasi muda yang mulia, berilmu, berbangsa dan bernegara dengan akhlak yang mulia. Adapun poin-poin dari nasihat tersebut adalah semua nasihat yang mengandung adanya hubungan antara kegiatan rohani dan kegiatan jasmani yang akan membangun serta menciptakan sikap kepribadian atau akhlak yang baik dan mulia. Sehingga, dapat disimpulkan konsep pendidikan akhlak Luqman Hakim adalah sebagai berikut :

a) Nasihat berupa selalu bersyukur

b) Ajaran Tauhid, yakni tidak menyekutukan Allah dengan lainnya

c) Berbakti dan taat kepada kedua orangtua

d) Berbuat baik terhadap keduanya

e) Nasihat berupa Amar Ma'ruf Nahi Munkar

f) Perintah selalu mendirikan sholat dan bersabar

g) Nasihat agar tidak bersikap angkuh dan sombong dan hidup dengan sederhana. 


\section{DAFTAR PUSTAKA}

Aida, M. (2019). Pendidikan Kecerdasan Spiritual Anak Dalam Perspektif Al-Qur'an Surah Luqman Ayat 12-19: Kajian Tafsir Al-Mishbah. https://doi.org/10.1017/CBO9781107415324.004

Anisah, A. S. (2011). Pola Asuh Orang Tua Dan Implikasinya Terhadap Pembentukan Karakter Anak. Jurnal Pendidikan Universitas Garut, 05(01), 70-84.

Arif, F. I, \& Agus, M. (2005). Studi Tokoh: Metode Penelitian Mengenai Tokoh. Yogyakarta: Pustaka Pelajar.

Ayu, S. (2015). Tafsir Surat Luqman Ayat 12-19 Tentang Pendidikan Anak Menurut Muhammad Quraish Shihab Dan Mahmud Yunus (Studi Komparasi).

Budi, P. (2018). Konsep Pendidikan Akhlaq Pada Al-Qur'an Surat Luqman Ayat 12-19 Menurut Tafsir Jalalain Dan Al-Maraghiserta Relevansinya Terhadap Pendidikan Karakter Santri.

Eka, P. (2017). Konsep Pendidikan Anak Menurut Al-Qur'an Perspektif Muhammad Quraish Shihab. Tadbir :Jurnal Manajemen Pendidikan Islam, 5(1), 116-131.

Emilya, U. (2017). Konsep Pendidikan Anak dalam Keluarga Perspektif Al-Quran (Analisis Kandungan Q.S. Ibrahim Ayat 35-41, Q.S. Luqman Ayat 12-19, dan Q.S. Ash-Shaaffat Ayat 100-113).

Halimah, T. D. (2017). Pendidikan Akhlak Dalam Al-Qur'an Surah Luqman Ayat 12-19 Studi Tafsir Al-Misbah. https://doi.org/10.1017/CBO9781107415324.004

Ilham, Y. (2017). Tujuan Pendidikan Islam Dalam Al-Qur'an Surat Luqman Ayat 13-19 (Studi Perbandingan Antara Tafsir Al-Qurthubi Dan Al-Misbah).

Khosiah, N. (2019). Pelaksanaan pendidikan karakter di m.i. Miftahul ulum tambakrejo tongas probolinggo Nur. Ar-Risalah: Media Keislaman, Pendidikan Dan Hukum Islam, 18(1).

Naimah, C., \& Hidayah, U. (2017). Reorientasi Pendidikan Islam untuk Harmonisasi Sosial: Hidden Curriculum sebagai Sebuah Tawaran. Proceedings of Annual Conference for Muslim Scholars, (Seri 2), 726-732. Retrieved from http://proceedings.kopertais4.or.id/index.php/ancoms/article/view/73

Nur, A. (2018). Pendidikan Anak Dalam Surat Luqman Ayat 12-19 Perspektif Tafsir Al-Misbah Karya M. Quraish Shihab.

Prasetiya, B. (2018). Dialektika Pendidikan Akhlak dalam Pandangan Ibnu Miskawaih dan AlGazali. Intiqad: Jurnal Agama Dan Pendidikan Islam, 9950(December), 249-267.

Prasetiya, B., Rofi, S., \& Setiawan, B. A. (2018). Penguatan Nilai Ketauhidan Dalam Praksis Pendidikan Islam. Journal of Islamic Education (JIE), III(1), 1-15.

Prasetiya, B., Safitri, M. M., \& Yulianti, A. (2019). Perilaku Religiusitas: Analisis Terhadap Konstribusi Kecerdasan Emosional Dan Spiritual. Al-Tadzkiyyah: Jurnal Pendidikan Islam, 10(2), 303-312. https://doi.org/10.24042/atjpi.v10i2.5015

Rofi, S., Prasetiya, B., \& Setiawan, B. A. (2019). Pendidikan Karakter Dengan Pendekatan Tasawuf Modern Hamka dan Transformatif Kontemporer. Intiqad, 11(2), 396-414.

Siti, N. (2016). Materi Pendidikan Agama Islam dalam Tafsir Al-Misbah (Surat Luqman Ayat 1219).

Suci, F. (2019). Nilai-Nilai Pendidikan Akhlak Dalam Al-Qur'an (Kajian Surat Luqman Ayat 13-19 dalam Tafsir Al-Misbah).

Susandi, A. (2020). Pendidikan Life Skills Dalam Penanaman Nilai-Nilai Agama Islam Di Sekolah Dasar. Al-Insyiroh: Jurnal Studi Keislaman, 6(2), 95-111. https://doi.org/10.35309/alinsyiroh.v6i2.3867

Syaefulloh. (2016). Konsep Pendidikan Akhlak dalam Persefektif Al-Quran Surat Al-Luqman Ayat 12-19. Jurnal Aksioma Ad-Diniyah, 4(2), 178-238.

Syahrul, M. (2016a). Konsep Pendidikan Akhlak Luqmanul Hakim (Kajian Tafsir Al Maragi dan Tafsir FI Zilalil Quran).

Syahrul, M. (2016b). Konsep Pendidikan Akhlak Luqmanul Hakim (Melalui Kajian Tafsir Al Maragī dan Tafsir FĪ Zilalil Quran).

Ulil, Hidayah, Benny, P. (2019). Multicultural Education In Madrasah Diniyah As Prevention Of Religious Conservatism. Jurnal Tarbiyah, 26(1), 168-184. https://doi.org/10.1017/CBO9781107415324.004 